\title{
PENGOPTIMALISASI PENDIDIKAN KARAKTER DALAM PEMBELAJARAN KIMIA YANG EFEKTIF DAN EFISIEN DENGAN MEDIA INTERAKTIF
}

\author{
Jafrinta Irma Ruta Astari ${ }^{1 *}$ \\ ${ }^{1}$ Jurusan Kimia FMIPA Univerasitas Negeri Semarang
}

\begin{abstract}
Abstrak - Pendidikan karakter adalah suatu sistem penanaman nilai-nilai karakter kepada warga sekolah yang meliputi komponen pengetahuan, kesadaran dan tindakan untuk melaksanakan nilai-nilai tersebut, baik terhadap Tuhan Yang Maha Esa, diri sendiri, sesama, lingkungan, maupun kebangsaan. Peran guru sangat penting dalam pendidikan karakter siswa. Penerapan pendidikan karakter dalam pembelajaran kimia secara nyata dapat menumbuhkan watak dan perilaku yang terpuji dari seluruh peserta didik sehingga sekolah akan mampu menghasilkan peserta didik yang berakhlak mulia, berkualitas, terampil dan kompetitif di semua bidang. Penggunaan media pembelajaran interaktif online memberikan pengaruh terhadap hasil belajar kimia yang lebih tinggi bila dibandingkan dengan penggunaan media pembelajaran interaktif offline.
\end{abstract}

\section{Kata kunci: Pendidikan Karakter, Pembelajaran Kimia, Peserta Didik, Media Interaktif}

\begin{abstract}
Character education is a system of inculcating the values of the character to the school community which includes the components of knowledge, awareness and action to implement those values, both toward God Almighty, self, fellow, environment, and nationality. The role of teachers is very important in character education students. The application of character education in learning chemistry can significantly cultivate the commendable character and behavior of all learners so that the school will can to produce learners who are noble, qualified, skilled and competitive in all fields. The use of interactive online learning media gives effect to higher learning result of chemistry when compared with use of interactive offline.
\end{abstract}

Keywords: Character, Character Education, Chemistry Learning, Student, Interactive Media

\section{PENDAHULUAN}

Pada era sekarang ini, sumber daya manusia yang baik banyak dibutuhkan terutama bagi negaranegara yang maju apalagi negara yang sedang berkembang contohnya Negara Indonesia. Sumber daya manusia yang baik ditentukan melalui tingkat pendidikannya. Pendidikan merupakan sarana untuk meningkatkan sumber daya manusia yang beriman dan bertakwa kepada Tuhan Yang Maha Esa, berakhlak mulia, sehat, berilmu, cakap, kreatif, mandiri, dan menjadi warga negara yang demokratis serta bertanggung jawab. Hal ini sesuai dengan tujuan pendidikan nasional di Indonesia.

Berdasarkan UU No. 20 Tahun 2003 Pasal 3 tentang Sistem Pendidikan Nasional, menyebutkan bahwa pendidikan nasional berfungsi mengembangkan kemampuan dan membentuk karakter serta peradaban bangsa yang bermartabat dalam rangka mencerdaskan kehidupan bangsa. Dalam pembentukan karakter (watak) peserta didik, rumusan dalam fungsi dan tujuan pendidikan nasional tersebut tidak secara nyata diimplementasikan dalam kebijakan pendidikan maupun

\footnotetext{
* Corresponding authors: Jurusan Kimia, Universitas Negeri Semarang, Indonesia. Email: jafrintairma12@gmail.com
} 
praktek di sekolah, baik dalam kegiatan proses belajar mengajar dalam kelas maupun di luar kelas. Berbagai kasus yang tidak sejalan dengan etika, norma, moral atau perilaku yang menunjukkan rendahnya karakter telah banyak terjadi dalam kehidupan di masyarakat.

Berbagai kasus yang pernah terjadi di Indonesia telah merusak keteladanan peserta didik dalam pembentukan karakter dan kepribadian yang mulia. Seperti tawuran mahasiswa dan antar pelajar, kasus kekerasan terhadap anak didik, kasus narkoba dan perjudian, pornografi dan pornoaksi yang ditunjukkan oleh kalangan siswa, hubungan seks bebas yang menjangkiti siswa dan mahasiswa, dan sebagainya.

Permasalahan yang diuraikan di atas, terjadi karena belum optimalnya penanaman nilai-nilai luhur pancasila terhadap peserta didik dalam kelas yang mengacu pada pembentukan karakter dan budaya bangsa Indonesia. Di samping itu, krisis keteladanan dan kurangnya panutan yang dicerminkan para pendidik, tokoh agama, birokrat pemerintah, elit politik dan elemen masyarakat sehingga menjadikan generasi penerus khususnya peserta didik tumbuh liar, memiliki karakter dan kepribadian yang lemah. Dengan ini sangat dibutuhkan peran dari guru dalam membentuk dan mengembangkan pendidikan karakter siswa dalam kelas. Guru harus terus berupaya membenahi dan mengembangkan pendidikan karakter yang melibatkan seluruh komunitas sekolah dalam kelas.

Selain itu pendidikan yang dapat membentuk atau mengembangkan karakter adalah pendidikan dalam pembelajaran kimia. Dalam pembelajaran kimia, sebagian besar materi dalam ilmu kimia adalah abstrak. Oleh karena itu, perlu adanya pemahaman yang baik dengan menerapkan media interaktif guna tercapainya pendidikan karakter yang baik sesuai dengan tujuan dari sistem pendidikan nasional di Indonesia. Pendidikan termasuk pendidikan kimia harus selalu diusahakan berjalan efektif. Pendidikan disebut efektif apabila proses pendidikan berhasil. Berhasil artinya memperoleh produk yang baik atau hasil belajar yang tinggi. Salah satu indikator efektivitas pendidikan kimia ditunjukkan tingginya nilai kimia yang dicapai peserta didik. Nilai tinggi mata pelajaran kimia baru dicapai sebagian kecil peserta didik, yaitu peserta didik di dalam kota dan belum merata pada peserta didik lainnya. Oleh karena itu efektivitas pendidikan kimia masih menjadi masalah hingga saat ini.

Dalam kaitan dengan penggunaan media pembelajaran interaktif, maka yang menjadi perhatian bagi setiap guru adalah bagaimana seorang guru mampu memilih dan menggunakan serta menyesuaikan dengan materi, sifat dan karakteristik ilmu pengetahuan serta karakteristik dari siswa. Penggunaan media dalam pembelajaran bertujuan untuk membantu siswa dalam penguasaan materi pelajaran dan memiliki keterampilan. Dalam hal ini guru harus benar-benar mampu mendesain proses pembelajaran dan menentukan materi yang akan disampaikan dan dengan media apa disajikan. Salah satu upaya yang dapat dilakukan adalah dengan penggunaan media pembelajaran interaktif, sehingga dapat mendorong siswa lebih mudah dalam memahami konsepkonsep pembelajaran Kimia.

Selain penggunaan media pembelajaran interaktif, guru juga harus dapat memperhatikan komunikasi interpersonal yang dimiliki oleh siswa. Keberhasilan belajar tergantung bagaimana siswa dapat menyampaikan kemampuan akan analisisnya terhadap pembelajaran Kimia yang pada akhirnya akan menciptakan siswa memiliki kemampuan berkomunikasi. Oleh sebab itu, penggunaan media pembelajaran interaktif perlu dikaji, apakah dapat meningkatkan hasil belajar kimia secara optimal. 


\section{PEMBAHASAN}

\section{Pendidikan karakter}

Menurut Suyanto (2009: 1) Pendidikan karakter adalah pendidikan budi pekerti plus, yaitu yang melibatkan aspek pengetahuan (cognitive), perasaan (feeling), dan tindakan (action). Menurut Thomas Lickona tanpa ketiga aspek ini pendidikan karakter tidak akan efektif. Pendidikan karakter menurut Jamal Ma'mur Asmani (2011: 31) adalah segala sesuatu yang dilakukan oleh guru untuk mempengaruhi karakter peserta didik. Guru membantu dalam watak peserta didik dengan cara memberikan keteladanan, cara berbicara atau menyampaikan materi yang baik, toleransi, dan berbagai hal yang terkaitnya. Pendidikan karakter adalah suatu sistem penanaman nilai-nilai karakter kepada warga sekolah yang meliputi komponen pengetahuan, kesadaran atau kemauan, dan tindakan untuk melaksanakan nilai-nilai tersebut, baik terhadap Tuhan Yang Maha Esa (YME), diri sendiri, sesama, lingkungan, maupun kebangsaansehingga menjadi manusia insan kamil (Prasetyo dan Rivasintha, 2011: 2).

Nilai-nilai pendidikan karakter yaitu yang bersumber dari agama, Pancasila, budaya, dan tujuan pendidikan nasional, yaitu: (1) Religius, (2) Jujur, (3) Toleransi, (4) Disiplin, (5) Kerja keras, (6)Kreatif, (7) Mandiri, (8)Demokratis, (9) Rasa Ingin Tahu, (10) Semangat Kebangsaan, (11) Cinta Tanah Air, (12) Menghargai Prestasi, (13) Bersahabat/Komunikatif, (14) Cinta Damai, (15) Gemar Membaca,(16) Peduli Lingkungan, (17) Peduli Sosial, \& (18) Tanggung Jawab (Puskurbuk, 2011: 3).

Pelaksanaan pembelajaran pendidikan karakter yang dituntut oleh Lickona Thomas (1992:54) yaitu "mempunyai dasar kurikulum yang mengandung nilai-nilai karakter dan terintegrasi dalam mata pelajaran yang akan diajarkan kepada peserta didik nantinya". Begitu juga dengan cara penilaian yang digunakan dalam pelaksanaan pendidikan karakter ini, yang mana penilaian yang harus dilakukan dengan mencantumkan nilai-nilai karakter yang telah tercapai oleh peserta didik baik dalam proses pembelajaran maupun di lingkungan sekitarnya.

Pelaksanaan pendidikan karakter di dalam pembelajaran. Menurut Tarmansyah, dkk. (2012:15) Dalam pendidikan karakter yang diintegrasikan didalam mata pelajaran, ada hal-hal yang perlu diperhatikan seperti:

a. Kebijakan sekolah dan dukungan administrasi sekolah terhadap pendidikan karakter yang meliputi: Visi dan misi pendidikan karakter, sosialisasi, dokumen pendidikan karakter dll.

b. Kondisi lingkungan sekolah meliputi: sarana dan prasarana yang mendukung, lingkungan yang bersih, kantin kejujuran, ruang keagamaan dll.

c. Pengetahuan dan sikap guru yang meliputi: konsep pendidikan karakter, cara membuat perencanaan pembelajaran, perangkat pembelajaran, kurikulum, silabus, RPP, bahan ajar, penilaian, pelaksanaan pendidikan karakter terintegrasi dalam mata pelajaran dll.

d. Peningkatan kompetensi guru.

e. Dukungan masyarakat.

Untuk memperoleh pendidikan yang efektif dan efisien, diwaktu yang akan datang dan secara bertahap dimulai tahun 2006, komponen-komponen pendidikan harus memenuhi standar minimal pendidikan. Dalam Pasal 2 ayat (1) PP RI 19 tahun 2005 (BSNP, 2005: 6) disebutkan lingkup Standar Nasional pendidikan meliputi: a. standar isi, b. standar proses, c. standar kompetensi lulusan, d. standar pendidik dan tenaga kependidikan, e. standar sarana dan prasarana, f. standar pengelolaan, g. standar pembiayaan, dan h. standar penilaian pendidikan.

Dalam Pasal 2 ayat (2) PP RI No. 19 tahun 2005 disebutkan bahwa penjaminan dan pengendalian mutu pendidikan sesuai dengan Standar Nasional Pendidikan dilakukan evaluasi, akreditasi, dan sertifikasi. Selanjutnya pada Pasal sama ayat (3) disebutkan bahwa Standar 
Nasional Pendidikan disempurnakan secara terencana, terarah, dan berkelanjutan sesuai dengan tuntutan perubahan kehidupan lokal, nasional, dan global. Mencermati pasal dan ayat di atas, pendidikan termasuk pendidikan kimia di masa datang, akan bersifat efektif, efisien, dan bermutu. Kedelapan standar tersebut di atas saat ini dalam penyusunan BSNP, standar isi dan buku teks mata pelajaran sebagai bagian standar sarana dan prasarana telah diberlakukan. Adalah suatu tantangan yang luar biasa bagi bangsa Indonesia untuk melaksanakan kedelapan standar tersebut, oleh karena masalah utama yaitu biaya pelaksanaan pendidikan menjadi mahal. Harapan kita semua, semoga anggaran pendidikan 20\% dari APBN dapat direalisasikan dalam waktu dekat. Dalam waktu transisi, pendidikan yang efektif dan efisien harus dicari jalan keluarnya oleh karena tantangan peningkatan mutu sudah di depan kita.

Proses pembelajaran secara sadar dan terencana yang dilakukan oleh para guru bersama peserta didik di dalam kelas untuk mencapai tujuan pembelajaran terutama perkembangan karakter siswa tentunya memerlukan keahlian tersendiri oleh guru terutama dalam hal pengelolaan kelas. Karena kelas merupakan lingkungan belajar serta merupakan suatu aspek dari lingkungan sekolah yang perlu diorganisir. Lingkungan ini perlu diatur dan diawasi agar kegiatan-kegiatan belajar terarah kepada tujuan-tujuan pendidikan. Lingkungan yang baik ialah yang bersifat menantang dan merangsang siswa untuk belajar, memberikan rasa aman dan kepuasan dalam mencapai hasil belajar yang diharapkan.

Proses belajar yang terjadi di ruang kelas menjadi rutinitas dari guru dan peserta didik, tujuan proses belajar adalah terjadinya perubahan tingkah laku dari peserta didik, salah satu yang harus terbentuk pada diri anak didik adalah karakter yang memunculkan potensi baik peserta didik dalam bertindak, cara pandang, berpikir, bersikap, dan gagasan. Karakter yang telah terbentuk ini diharapkan menjadi jati diri yang melekat pada anak didik samapi masa depannya.

Pembentukan karakter anak didik merupakan kegiatan guru yang luar biasa dan hanya mampu dilakukan oleh guru yang sangat memahami tujuan pendidikan yang sebenarnya. Dalam penggunaan wahana kelas sebagai salah satu media pembentukan anak didik karena kelas merupakan tempat rutinitas guru dan peserta didik. Guru yang dapat mengoptimalisasi kelas sebagai ruang pembentuk karakter peserta didik adalah:

1. Guru yang memiliki kinerja dan pemahaman yang benar tentang proses pembelajaran yang berkarakter

2. Guru yang menguasai dan memiliki kemampuan dasar mengajar dengan baik mulai dari keterampilan bertanya, keterampilan memberi penguatan, keterampilan mengadakan variasi, keterampilan menjelaskan, keterampilan membuka dan menutup, keterampilan membimbing diskusi kelompok kecil, keterampilan mengelola kelas, keterampilan mengajar kelompok kecil dan perorangan.

3. Guru menguasai dan memiliki kemampuan manajemen kelas baik manajerial maupun manajemen psikologis. hasil penelitian.

\section{Pendidikan Kimia}

Pendidikan kimia di SMA/MA bertujuan agar peserta didik menguasai standar kompetensi lulusan SMA/MA, standar kompetensi kelompok mata pelajaran sains dan teknologi, standar kompetensi dan kompetensi dasar mata pelajaran kimia, memiliki sikap ilmiah, dan mampu melaksanakan kerja ilmiah sebagaimana yang telah ditetapkan dalam standar isi mata pelajaran kimia SMA/MA (BSNP, 2006: 2). Standar isi mata pelajaran kimia terdapat dalam Permendiknas No. 22 Tahun 2006 tentang standar isi untuk satuan pendidikan dasar dan menengah (Permendiknas No. 22, 2006: 1) berisi empat hal, yaitu:.

a. Kerangka dasar dan struktur kurikulum yang merupakan pedoman dalam penyusunan kurikulum pada tingkat satuan pendidikan. 
b. Beban belajar bagi peserta didik pada satuan pendidikan dasar dan menengah

c. Kurikulum tingkat satuan pendidikan (KTSP) yang akan dikembangkan oleh satuan pendidikan berdasarkan panduan penyusunan kurikulum sebagai bagian tidak terpisahkan dari standar isi, dan

d. Kalender pendidikan untuk penyelenggaraan pendidikan pada satuan pendidikan jenjang pendidikan dasar dan menengah.

Lampiran 1, 2, dan 3 Permendiknas No. 22 Tahun 2005 berupa standar kompetensi dan kompetensi dasar mata pelajaran untuk pendidikan dasar dan menengah, baik umum maupun kejuruan. Termasuk dalam hal ini ialah standar kompetensi dan kompetensi dasar mata pelajaran kimia untuk SMA/MA. Standar kompetensi (SK) dan kompetensi dasar (KD), yang terbagi menjadi enam semester, yaitu kelas X semester 1 dan 2, kelas XI semester 1 dan 2, serta kelas XII semester 1 dan 2 .

Pada pendidikan kimia, dalam proses pembelajarannya ada pemahaman tentang tiga jenis representasi yang digunakan dalam kimia makroskopis, submikroskopis dan simbolik merupakan landasan dalam berbagai penjelasan yang menyumbang terhadap 'literasi kimia'. Tantangannya adalah kapan dan bagaimana mengenalkan 'triplet representasi' tersebut untuk menghindari konsep-konsep alternatif dan miskonsepsi yang banyak ditunjukkan oleh hasil.

Pemahaman konsep kimia mencakup kemampuan untuk merepresentasikan/ menggambarkan dan menterjemahkan fenomena kimia dengan menggunakan representasi makroskopis, submikroskopis, dan simbolik (Johnstone, 1993; Gabel \& Bunce, 1994). Pada tingkat makroskopis, kimia mencakup fenomena yang dapat diamati dan bisa dijumpai oleh siswa dalam kehidupan sehari-hari, misalnya es mencair, atau paku berkarat. Agar dapat menjelaskan fenomena ini dengan baik, maka kimiawan mengembangkan konsep dan model atom atau molekul.

Pada tingkat submikroskopis, paku yang berkarat menjadi proses kimia dimana atom- atom besi bereaksi dengan molekul oksigen di udara dan menghasilkan molekul besi oksida. Cara lain untuk mengggambarkan proses ini adalah dengan menggunakan persamaan reaksi kimia beserta simbolsimbol, rumus kimia dan angka-angka, misalnya $4 \mathrm{Fe}(\mathrm{s})+3 \mathrm{O}_{2}(\mathrm{~g}) \rightarrow 2 \mathrm{Fe}_{2} \mathrm{O}_{3}(\mathrm{~s})$. Seperti yang diilustrasikan dalam contoh ini, kimiawan menggambarkan pengalaman indera dengan menggunakan atom, molekul dan menterjemahkannya kedalam symbol-simbol dan rumus kimia.

Kemampuan siswa dalam memahami peran setiap level representasi kimia dan dalam mentransfer dari satu tingkat ke tingkatan lainnya merupakan aspek yang sangat penting agar menghasilkan penjelasan yang bisa dimengerti (Treagust, Chittleborough, \& Mamiala, 2003) dan juga ketiga representasi ini berperan penting dalam memahami hakekat kimia, norma- norma dan metodenya (Shwartz dkk, 2006) dan juga merupakan penyumbang kunci dalam uraian atau penjelasan fenomena kimia. Oleh karena itu, penting sekali bagi pendidik untuk mengembangkan "kompetensi merepresentasi/menggambarkan (representatational competence)" siswa dalam belajar kimia.

Hal ini berkaitan dengan bagaimana mengembangkan kurikulum, pendekatan pembelajaran yang cocok dan teknik asesmennya (Kozma \& Russell, 1997). Isu-isu tentang kompetensi siswa dalam merepresentasi dan cara mengembangkan kompetensi tersebut, pengembangan kurikulum yang mendukungnya, langkah-langkah pembelajaran di kelas dan teknik asesmennya merupakan isu-isu prospektif yang bisa dieksplorasi lebih lanjut melalui penelitian pendidikan kimia. Salah satu pakar penelitian pendidikan kimia dari Curtin University, Prof. David Treagust, yang juga sebagai co-author dengan penulis menyarankan untuk mengangkat isu integrasi 'triplet representasi' kedalam kurikulum, pendekatan pembelajaran dan pengembangan tes diagnosik/asesmen (komunikasi pribadi).

Pada konsep pembelajaran kimia, perkembangan media itu berpotensi untuk tumbuh dan berkembangnya peserta didik dalam belajar. Oleh karena itu dalam setiap kegiatan belajar mengajar 
potensi media tidak mungkin diabaikan (Miarso, 2004:456). Menurut Dabbagh \& Ritland (2005:15) pembelajaran interaktif online adalah sistem belajar yang terbuka dan tersebar dengan menggunakan perangkat pedagogi (alat bantu pendidikan), yang dimungkinkan melalui internet dan teknologi berbasis jaringan untuk memfasilitasi pembentukan proses belajar dan pengetahuan melalui aksi dan interaksi yang berarti.

Media pembelajaran interaktif online dapat diartikan sebagai media yang dilengkapi dengan alat pengontrol yang dapat dioperasikan oleh pengguna (user), sehingga pengguna (user) dapat mengendalikan dan mengakses apa yang menjadi kebutuhan pengguna, misalnya mengunduh sumber-sumber untuk materi sifat-sifat senyawa organik atas dasar gugus fungsi dan senyawa makromolekul pada pelajaran kimia.

Keuntungan penggunaan media pembelajaran interaktif online adalah pembelajaran bersifat mandiri dan interaktivitas yang tinggi, mampu meningkatkan tingkat ingatan, memberikan lebih banyak pengalaman belajar, dengan teks, audio, video dan animasi yang semuanya digunakan untuk menyampaikan informasi, dan juga memberikan kemudahan menyampaikan, meng-update isi, mengunduh, para siswa juga bisa mengirim email kepada siswa lain, mengirim komentar pada forum diskusi, memakai ruang chat, hingga link video conference untuk berkomunikasi langsung.

Sedangkan Media pembelajaran interaktif offline dapat diartikan sebagai media yang tidak dilengkapi dengan alat pengontrol/navigasi yang dapat digunakan oleh pengguna (user). Media ini berjalan secara berurutan (in sequence). Misalnya media persentasi yang pada umumnya tidak dilengkapi alat untuk mengontrol apa yang akan dilakukan oleh pengguna. Persentasi berjalan sekuensial sebagai garis lurus sehingga dapat disebut media linier dan biasanya digunakan bila jumlah audiens lebih dari satu orang, sebagai contoh dapat dapat diwujudkan dalam bentuk CD.

Untuk mengetahui hasil dari pemahaman kosep dalam pembelajaran kimia pada peserta didik dilakukanlah penilaian. Penilaian pendidikan merupakan tahap akhir dari proses pendidikan atau pembelajaran. Penilaian adalah proses sistematik mengumpulkan, menganalisis, dan menginterpretasikan informasi hasil pendidikan untuk menentukan seberapa jauh peserta didik telah menguasai kompetensi belajar yang ditentukan. Tujuan utama penilaian pendidikan adalah untuk mengetahui efektivitas hasil pendidikan. Objek penilaian pendidikan adalah hasil pendidikan dalam dimensi proses kognitif, afektif, dan psikomotor. Penilaian pendidikan terutama berfungsi untuk mengetahui keberhasilan atau efektivitas dan refleksi terhadap peserta didik.

Dalam sistem penilaian ada dua hal penting, yaitu teknik penilaian dan instrumen penilaian. Selama ini dikenal dua teknik penilaian yaitu ujian dan non-ujian (observasi, wawancara, dan angket). Instrumen penilaian dapat berbentuk soal dan non-soal (lembar observasi, lembar wawancara, dan lembar angket). Dengan penilaian alternatif, guru kimia dapat merekam hasil belajar peserta didik dalam spektrum yang lebih luas dan efektivitas pembelajaran menjadi lebih efektif. Dipihak lain pelaksanaan penilaian alternatif menuntut lingkup kerja dan waktu lebih banyak.

\section{KESIMPULAN}

Pendidikan karakter dalam pembelajan kimia digunakan untuk membantu tercapainya tujuan pendidikan nasional. Melalui peran serta guru dalam mendukung setiap upaya penerapan pendidikan karakter, diharapkan mampu mempercepat proses integrasi nilai-nilai karakter dalam diri komunitas sekolah dan menjadikannya sebagai perilaku dalam kehidupan sehari-hari. Penerapan pendidikan karakter bangsa secara nyata dapat menumbuhkan watak dan perilaku yang terpuji dari seluruh komunitas sekolah, sehingga sekolah akan mampu membentuk dan menghasilkan peserta didik yang berakhlak mulia, berkualitas, terampil dan kompetitif. 
Penggunaan media pembelajaran interaktif online memberikan pengaruh terhadap hasil belajar kimia yang lebih tinggi bila dibandingkan dengan penggunaan media pembelajaran interaktif offline. Karena media pembelajaran interaktif online adalah pembelajaran bersifat mandiri dan interaktivitas yang tinggi, mampu meningkatkan tingkat ingatan, memberikan lebih banyak pengalaman belajar, dengan teks, audio, video dan animasi yang semuanya digunakan untuk menyampaikan informasi, dan juga memberikan kemudahan menyampaikan, mengupdate isi, mengunduh, para siswa juga bisa mengirim email kepada siswa lain, mengirim komentar pada forum diskusi, memakai ruang chat, hingga link video conference untuk berkomunikasi langsung.

Pembelajaran kimia dengan metode interaktif terutama media interaktif online meningkatkan proses pembelajaran kimia terhadap peserta didik. Dengan ini proses pembelajaran kimia lebih efektif serta efisien dan pemahaman peserta didik pada konsep pendidikan kimia lebih meningkat.

\section{DAFTAR RUJUKAN}

BSNP. (2006). Peraturan Menteri Pendidikan Nasional Nomor 22, 23, dan 24 Tahun 2006 No. 19 dan 20 Tahun 2007 Jakarta: Badan Standar Nasional Pendidikan.

Dabbagh, N. \& Ritland. B. B. (2005). Online Learning, Concepts, Strategies and Application. Ohio: Pearson.

Kozma, R. B., \& Russell, J. (1997). Multimedia and understanding: expert and novice responses to different representations of chemical phenomena. Journal of Research in Science Teaching, 34 (9), 949-968

Lickona, Thomas. (1991). Educating for Character, How Our School Can TeachRespect and Responsibility. New York : Bantam Books.

Shwartz, Y., Ben-Zwi, R, \& Hofstein, A. (2006). The use of sciencetific literacy taxonomy for assessing the development of chemical literacy among high-school students. Chemical Education Research and Practice, 74(4), 203-225.

Tarmansyah, dkk. (2012). Pedoman Pengembangan Pendidikan Karakter Di Sekolah Inklusif. Padang: Direktorat Pembinaan Pendidikan Khusus dan Layanan Khusus (PK-LK) Direktorat Pendidikan Dasar.

Treagust, D. F., Chittleborough, G., \& Mamiala, T. L. (2003). The role of submicroscopic and symbolic representations in chemical explanation. International Journal of Science Education, 25(11), 1353-1368.

Prasetyo, A., dan Rivasintha, E. (2010). Konsep, Urgensi, dan Implementasi Pendidikan Karakter di Sekolah, (Online). (http://edukasi. kompasiana.com, diakses 16 April 2018)

UU No 20 Tahun 2003 Tentang Sistem Pendidikan Nasional. 